\title{
Analysis of Zakat Performance of Central Java Province
}

\author{
Isro'iyatul Mubarokah, Irfan Syauqi Beik, Tony Irawan
}

Bogor Agricultural University

\begin{abstract}
The Indonesian province with the third largest Muslim population is Central Java. This suggests a great potential for zakat collection. However, the amount accumulated is far from significant. This study aims to determine zakat performance in Central Java Province at macro and micro levels. Data collection involved distributing questionnaires during interviews. This study employed a convenience sampling technique. The analytical tool used in this research is National Zakat Index (NZI). National Zakat Index is an indicator that illustrates the extent to which charity has been instrumental to the mustahik welfare. It also indicates the initial stages of zakat development in terms of internally and at a community level, as well as highlight the support provided by the government. Findings indicate that zakat performance of Central Java Province from a macro dimension is poor, while from a micro prospective it is decent.
\end{abstract}

Keywords: macro dimension, micro dimension, National Zakat Index (NZI), zakat performance

\section{INTRODUCTION}

Central Java is the Indonesian province with the third largest Muslim population, after West Java and East Java. The Ministry of Religious Affairs Statistics indicate that the Moslem population in Central Java reached 31,328,341 people in 2010. This suggests a very high potential of zakat in Central Java. Research conducted by Firdaus et.al (2010) speculates that the potential of zakat in Central Java Province is Rp 13.28 T.

However, the amount of zakat collection in Central Java is considerably substandard. During 2015 to 2016, BAZNAS Central Java Province, a provincial level zakat amil institution, only collected zakat funds amounting to Rp 8.6 M. Consequentially, performance of zakat management institutions/organizations in Central Java is suboptimal.

Zakat management institutions require a measurement support indicator that will aid in the achievement of charity objectives. This is especially the case in Central Java province, particularly BAZNAS Central Java province. The National Zakat Index is an indicator that will illustrate the extent to which charity has been instrumental to the mustahik welfare, indicate initial stages of zakat development in terms of internally and at a community level, and highlight the support provided by the government. The purpose of the National Zakat index is to measure zakat at the national, provincial and city district level. This study aims to determine the zakat performance of Central Java province from a macro perspective, taking regulation, state budget support, database zakat agencies and institutions into account. This study will also determine the zakat performance of Central Java from a micro perspective, with respect to the institution and impact of zakat. 


\section{LITERATURE REVIEW}

\section{Measurement of Zakat Performance}

Several studies have produced indicators used to measure the performance of zakat, such as Zakat Effectiveness Index and Zakat Index. Abdullah et al (2012) created the Zakat Effectiveness Index upon understanding their methodological and practical issues as associated with indices of poverty and inequality in poverty alleviation efforts. Zakat Effectiveness Index measures poverty reduction with a focus on consumer and government spending and the number of recipients. This index has three strengths: it verifies and compares how effective government spending is on poverty reduction, represented by the amount of zakat distributed to eligible recipients; it is flexible enough to incorporate the analysis of different sub-groups such as the type of job, sector or ethnic group; and unlike other indexes that use GNP and GDP as the denominator, ZEIN introduce the recipients as the denominator to increase the effectiveness of the poverty index (Abdullah et al., 2012). Zakat effectiveness index value is divided into three groups: Relatively less needy (zakat effectiveness index value $<0.50$ ), moderately needy (zakat effectiveness index value of between 0.50- 0.75), and the very needy (zakat effectiveness index values> 0.75$)$.

The Zakat index model measures performance of the charitable organization. This model proposes a process approach for measuring organizational performance of zakat, using four components (input, process, output, and outcome). Noor et al (2012) state that the zakat index demonstrates the ability of the charitable organization to operate at an optimum level and efficient. This index has the ability to measure the magnitude of change over time or place.

In Indonesia, Beik (2009) has also used some analytical tools to measure the impact of zakat. The analysis tool is headcount ratio, which describes the number and percentage of poor families. The ratio of the poverty gap and the income gap ratio determines the level of depth of poverty. Both the Sen Index and the Foster, Greer and Thorbecke (FGT) indices, measure the severity of poverty. This study was later refined by Beik and Arsyianti (2015), producing the CIBEST Model. CIBEST model is a measure of poverty that measures beyond the material poverty, capturing the spiritual poverty as well. The model consists of CIBEST quadrant CIBEST and CIBEST index. CIBEST Quadrant is a quadrant that aims to map out the family in four areas, namely the welfare areas (quadrant), material poverty areas (quadrant II), the spiritual poverty areas (quadrant III), and the absolute poverty areas (quadrant IV). The CIBEST index finds the value of the index in each quadrant CIBEST (Beik and Arsyianti 2015).

Nurzaman (2011) modified the Human Development Index. The modified HDI is a measure of prosperity to households of mustahik. The index value is calculated as the simple average of: (1) Life expectancy index, measured by life expectancy; (2) Education Index measured by the literacy rate and the average length of the school; and (3) Index of income, measured by the average adjusted real consumption or real per capita income tailored to the strengths of each family purchases. HDI value ranges from " 0 " to "100". This means that the lower of the HDI value of community/household means the weak/lagging development of society. This approach uses several characteristics of respondents targeted and combined with a national average of data.

\section{National Zakat Index}

National Zakat Index (NZI), prepared by the Center of Strategic Studies Team (Puskas) BAZNAS, is a composite index 
that measures the development of zakat nationally. NZI is an indicator that can provide information on the role of zakat to the zakat recipients' welfare, and can also indicate development stages of zakat institutions, starting from the internal institution, community participation, until the support provided by the government.

NZI was developed using a mixed method research approach. Mixed method research methodologies integrate quantitative and qualitative method. In this study, a qualitative method was used to compile NZI components, and a quantitative method approach was taken to form the estimation model of calculations. In determining the components that construct NZI, the Puskas research team set a guideline that became a concept for the whole process of preparing the index. The SMART guideline requires that the components of the index meet the criteria of Specific, Measurable, Applicable, Reliable, and Timely.

a. Specific; components presented must be specific

b. Measurable; components presented must be measurable

c. Applicable; components presented can be applied

d. Reliable; components presented are trustworthy

e. Timely; calculation is conducted in a periodical manner

NZI forming components derive from existing studies, divided into macro and micro dimension. Both dimensions breakdown into a number of components that are more detailed. Furthermore, each component also has a weight contribution that was determined through the mechanism of FGD and expert judgment criteria.

Table 1. Component of National Zakat Index

\begin{tabular}{|c|c|c|c|c|c|}
\hline $\begin{array}{l}\text { Dime } \\
\text { nsion }\end{array}$ & $\begin{array}{l}\text { Weighte } \\
\text { d score }\end{array}$ & Indicator & $\begin{array}{l}\text { Weighte } \\
\text { d score }\end{array}$ & Variable & $\begin{array}{l}\text { Weighte } \\
\text { d score }\end{array}$ \\
\hline \multirow{10}{*}{$\begin{array}{l}\text { Macro } \\
\left(\mathrm{X}_{1}\right)\end{array}$} & \multirow{10}{*}{0.40} & Regulation $\left(\mathrm{X}_{11}\right)$ & 0.30 & Regulation & 1.00 \\
\hline & & $\begin{array}{l}\text { Government } \\
\text { budget }\left(\mathrm{X}_{12}\right)\end{array}$ & 0.40 & Government budget & 1.00 \\
\hline & & \multirow{3}{*}{$\begin{array}{l}\text { Zakat Institution } \\
\text { database }\left(\mathrm{X}_{13}\right)\end{array}$} & \multirow{3}{*}{0.30} & $\begin{array}{l}\text { Number of official zakat } \\
\left(\mathrm{X}_{131}\right)\end{array}$ & 0.33 \\
\hline & & & & $\begin{array}{c}\text { Individual Muzakki } \\
\text { Ratio }\left(\mathrm{X}_{132}\right)\end{array}$ & 0.33 \\
\hline & & & & $\begin{array}{c}\text { Enterprise Muzakki Ratio } \\
\qquad\left(\mathrm{X}_{133}\right)\end{array}$ & 0.33 \\
\hline & & \multirow{5}{*}{ Institutional $\left(\mathrm{X}_{21}\right)$} & \multirow{5}{*}{0.40} & Collection $\left(\mathrm{X}_{211}\right)$ & 0.30 \\
\hline & & & & Management $\left(\mathrm{X}_{212}\right)$ & 0.20 \\
\hline & & & & Distribution $\left(\mathrm{X}_{213}\right)$ & 0.30 \\
\hline & & & & Reporting (X 214$)$ & 0.20 \\
\hline & & & & $\begin{array}{l}\text { Material and Spiritual } \\
\quad(\mathrm{CIBEST})\left(\mathrm{X}_{221}\right)\end{array}$ & \\
\hline \multirow{3}{*}{$\begin{array}{l}\text { Micro } \\
\left(\mathrm{X}_{2}\right)\end{array}$} & \multirow{3}{*}{0.60} & \multirow{3}{*}{$\begin{array}{l}\text { Impact of Zakat } \\
\qquad\left(\mathrm{X}_{22}\right)\end{array}$} & & & 0.40 \\
\hline & & & \multirow{2}{*}{0.60} & Education and Health & \\
\hline & & & & (HDI Modified) (X 222$)$ & 0.40 \\
\hline
\end{tabular}

Source: Center of Strategic Studies The National Zakat Board The Republic of Indonesia 2016

Categorization of the obtained components of NZI involved macro and micro dimensions. The macro dimension reflects the role of government and the 
aggregate society in developing zakat institutions. This dimension has three indicators, namely regulation, government budget (APBN), and database of zakat institutions. Except for regulation and government budget support, the indicator database of zakat institution is subdivided into three variables: the number of official zakat institutions, individual muzaki, and enterprise muzaki. The micro dimension denotes the perspective of zakat institutions and zakat recipients or mustahik. Technically, the micro dimension has two indicators, the performance of zakat institutions and the impact of zakat to mustahik. Performance indicators of zakat institutions are further divided into 4 variables that measure the performance of the institution from the aspect of collection, management, distribution, and reporting. Zakat impact indicators are a combination of five variables: economic, spiritual, education, health, and independency. Table 1 offers a comprehensive overview of the components of NZI, along with the weighted score for each component.

The estimation technique of calculating the value of NZI employs a method called Multi-Stage Weighted Index. The method combines several processes of weighting stages that are given to each index components so that the weighted score to each component must be performed gradually and procedurally. The weighting process occurs after the index for each variable is calculated. The index range is 0.00 to 1.00 . This means that the lower index value, the worse the performance of national Zakat, while the larger the index value means better conditions for the national zakat. The value of 0.00 signifies that the National zakat index obtained is the lowest, which is "zero". The value of 1.00 denotes the highest index, which is "perfect".

The National Zakat Index should become a performance measurement standard of national zakat which is measured periodically (e.g. every year) so the evaluation is sustainable. In addition to the national level, NZI is applicable at the regional level, to allow for comparison of local provinces' performance of Zakat distribution. Moreover, at each of its constituent components - such as at the institution aspect - the index in regards to the institution can be calculated separately. In other words, it is possible to apply NZI in zakat management institutions both at the national level and the region level. This enables stakeholders to measure themselves and improve their performance in zakat, and improves public understanding of zakat contribution for Indonesia.

\section{METHODOLOGY}

\section{Types and Sources of Data}

This study uses primary and secondary data. The primary data was obtained through a questionnaire distributed to respondents. The secondary data was obtained from reports from BAZNAS Central Java, Central Java BPS website, Semarang BPS website and WHO websites.

\section{Time and Location Research}

The BAZNAS Central Java province institutions case study was conducted from March to April 2017. Secondary case studies focused on mustahik, who receive zakat distribution of BAZNAS Central Java province.

\section{Sampling}

The sample included 101 respondents representing one agency, importantly the general treasurer of BAZNAS Central Java Province, and 100 mustahik who received zakat distribution from BAZNAS Central Java Province's economic program in 
2016. Due to data completeness limitations, the sample reduces to only respondents that are fully recorded by BAZNAS Central Java Province and are easy to find. Therefore, the method used in sampling is the convenience sampling method. The number of mustahik samples is determined by the slovin formula as follows:

$n=\frac{N}{1+N e^{2}}=\frac{1080}{1+1080 \times 0,1^{2}}=97.5$

where

$n$ : total sample

$\mathrm{N}$ : total population

e : error tolerance

The number of mustahik for the economic program in BAZNAS Central Java Province in 2016 is as many as 1,080. The fault tolerance limit used by the researchers is $10 \%$. Based on formula calculations, slovin get a sample of 97.5 which researchers round up to 100 samples.

\section{Analysis Methods}

The analysis tool used is the National Zakat Index (NZI) (Center of Strategic Studies BAZNAS 2016). The estimation technique of calculating the value of NZI employs a Multi-Stage Weighted Index method. The method combines several processes of weighting stages that are assigned to each index component so that the weighted score of each component must be performed gradually and procedurally.

Overall index estimation procedure is as follows:

The first section uses the likert scale that ranges from 1 to 5 , where one describes the worst condition, and five describes the most excellent condition. The overall constituent variable Index is scored.
The second section, calculates the index of each variable. The formula for calculating the index on each variable is as below:

$\mathrm{Ii}=\frac{(\mathrm{Si}-\mathrm{Smin})}{(\mathrm{Smax}-\mathrm{Smin})}$

where

Ii : index variable $\mathrm{i}$

$\mathrm{Si} \quad$ : value of the actual score variable $\mathrm{i}$

Smax : maximum score

Smin : minimum score

The index value ranges from $0.00-$ 1.00. Lower values indicate poor performance of the national zakat, and greater values indicate a better zakat condition, as represented below.

0.00-0.20: not good performance

$0.21-0.40$ : poor performance

$0.41-0.60$ : fairly good performance

0.61-0.80 : good performance

0.81-1.00 : very good performance

The third stage, multiplies the index obtained on each variable with respective weights to derive the index on the indicator. The two indicators, regulation and government budgets, are not further broken down, so they do not require further calculations at this stage. Another three indicators break down into several variables with a certain calculation. Those are:

$\mathrm{X}_{13}=0.33 \mathrm{X}_{131}+0.33 \mathrm{X}_{132}+0.33 \mathrm{X}_{133}$

where

X13 : Indicator index of database of zakat institution

X131: Variable index of total number of official zakat institutions

X132 : Variable index of individual muzaki ratio against the number of households 
X133 : Variable index of enterprise muzaki ratio against the total number of enterprises

$\mathrm{X}_{21}=0.30 \mathrm{X}_{211}+0.20 \mathrm{X}_{212}+0.30 \mathrm{X}_{213}+$ $0.20 \mathrm{X}_{214}$

where

X21 : Indicator index of institution

X211 : Variable index of collection

X212 : Variable index of management

X213 : Variable index of distribution

X214 : Variable index of reporting

$\mathrm{X}_{22}=0.40 \mathrm{X}_{221}+0.40 \mathrm{X}_{222}+0.20 \mathrm{X}_{223}$

where

$\mathrm{X}_{22}$ : Indicator index of zakat impact

$\mathrm{X}_{221}$ : Variable index of material and spiritual (CIBEST)

$\mathrm{X}_{222}$ : Variable index of education and health (Modified HDI)

$\mathrm{X}_{223}$ : Variable index of Independence

In this study, finding the value of Material Value (MV), or household poverty and household income per month, must occur before the creation of a welfare index calculation CIBEST. Material Value (MV) measures the minimum standards of material that households must hold. MV value is obtained by multiplying the price of goods and services consumed (Pi) with the minimal amount of goods and services required (Mi). Mathematically, the MV can be formulated as follows:

$\mathrm{MV}=\sum_{\mathrm{i}=1}^{\mathrm{n}} \mathrm{PiMi}$

where

MV : minimum material needs standard (in term of RP or local currency)

$\mathrm{Pi} \quad$ : Price of goods and services (in term of RP or local currency)

Mi : minimum number of goods and services I need

Due to their intrinsic limitations and absence of a survey in this study, the
MV value used in this study is the existing poverty line material Kota Semarang, converted into a poverty line household per capita per month. The calculation of the poverty line is obtained by multiplying the poverty line per capita per month by the average amount of household size. The average household size scale derives from the ratio of the total population by the number of households in the regions studied.

The poverty line is based on Semarang in 2015 and amounts to Rp 368 477 (BPS Semarang 2015). The research area covered all districts in the city of Semarang with a total population of 1,595,187 people and 471327 households (BPS Semarang 2015)

Average household size:

$$
\frac{1.595 .187}{471.327}=3,384
$$

So the household poverty line (MV) obtained are:

$$
\begin{aligned}
\text { MV }= & \operatorname{Rp~} 368,477 \times 3,384 \\
= & \operatorname{Rp~1,246,926~per~household~per~} \\
& \text { month }
\end{aligned}
$$

Spiritual poverty line or spiritual Value (SV) is obtained based on the indicator of spiritual needs and the fulfillment of the five variables. The five variables are prayers, alms, fasting, household environment, and government policies. A Likert scale of 1-5 was used to assess the variable score (see appendix).

Based on the table above, the obtained value $\mathrm{SV}$ is equal to three. If a household has a score of less than or equal to three it can be categorized as a spiritually poor household. SV value calculation is:

$$
\mathrm{Hi}=\frac{\mathrm{Vp}+\mathrm{Vf}+\mathrm{Vz}+\mathrm{Vh}+\mathrm{Vg}}{5}
$$

where

$\mathrm{Hi}$ : Actual spiritual score of household member i

Vpi : Prayer score of household member i 
Vfi : fasting score of household member i

Vzi : Score of zakat and infak of household member $\mathrm{i}$

Vhi : Score of household environment based on perception of household member i
Vgi : Score of government policy environment based on perception of household member i

After determining $\mathrm{MV}$ and SV of each household, each household is grouped into the CIBEST quadrant by combining their spiritual and material scores.

Table 2. Combination of MV and SV value

\begin{tabular}{lll}
\hline Result & $\leq$ MV value & $>$ MV value \\
\hline$>$ SV value & $\begin{array}{l}\text { Materially Poor and Spiritual } \\
\text { Rich Household } \\
\text { (Quadrant II) }\end{array}$ & $\begin{array}{l}\text { Materially and Spiritually Rich } \\
\text { Household } \\
\text { (Quadrant I) }\end{array}$ \\
& $\begin{array}{l}\text { Materially and Spiritually Poor } \\
\text { Household } \\
\text { (Quadrant IV) }\end{array}$ & $\begin{array}{l}\text { Materially Rich and Spiritually } \\
\text { Poor Household } \\
\text { (Quadrant III) }\end{array}$ \\
\hline
\end{tabular}

The welfare index (W) determines which households fall into quadrant I. In this quadrant, households are prosperous. The Welfare index value (W) formula is:

$\mathrm{W}=\frac{\mathrm{w}}{\mathrm{N}}$

where

$\mathrm{W}$ : welfare index $(0 \leq \mathrm{W} \leq 1)$

$\mathrm{w}$ : the number of spiritually and materially rich household

$\mathrm{N}$ : the total number of observed household

\section{Education Index}

The knowledge index uses two indicators, namely an average length of school and literacy rate. The knowledge index formula is:

Education Index $=\{2 / 3[($ Lit-0) $/(100-0)]+$ $1 / 3[($ LS- 0$) /(15-0)] \times 100\} \quad$ (v.iv)

where

Lit : Literacy rates

LS : length of school experience

0 : minimum rate for literacy and length of school

100 : Maximum number of Lit

15 : The minimum number for LS

Table 3. Education and Literacy Rate Convertion

\begin{tabular}{llll}
\hline No & The Highest Level of Education & Year Conversion & Literacy Rate \\
\hline 1 & No School & 0 & 0 \\
2 & SD (Elementary) & 6 & 40 \\
3 & SMP (Junior High School) & 9 & 60 \\
4 & SMA (Senior High School) & 12 & 80 \\
5 & Diploma 1 & 13 & 86,7 \\
6 & Diploma 2 & 14 & 93,3 \\
7 & Diploma 3 & 15 & 100 \\
8 & Bachelor Degree & 16 & 100 \\
9 & Master Degree & 18 & 100 \\
10 & Doctorate Degree & 21 & 100 \\
\hline
\end{tabular}




\section{Health Index}

The health index use life expectancy. As suggested by Torre and Moreno (2010), life expectancy estimation is at the family level and will be adjusted with income and age variables through an imputation method. This study added the healthy information variable.

Model specification is as follows: $\hat{\mathrm{Y}}=\mathrm{a}_{0}+\mathrm{b}_{1}($ ln income $\mathrm{f})+\mathrm{b}_{2}$ (gender $)+\mathrm{b}_{3}$ $($ age $)+b_{4}(\text { age })^{2}+b_{5}$ (healthy info) $+u$

The model is explained below:

Where $\mathrm{Y}$ is the life expectancy by age (a), gender (g) based on secondary data available. Due to limited statistics in Indonesia, the value of life expectancy based on age will be taken from the World Health Organization. Since the data available is in 5 year-age classifications, the life expectancy of each respondent will be incorporated into this existing classification range of year 0 - year 100 . Then, income $f$ is the per capita income for each family and gen is the dummy variable for gender.

The second stage of calculating the value of life expectancy at the household level is by taking into account the life expectancy of an individual (i), which has been adjusted to every individual in the sample. Individual life expectancy index is calculated as follows:

$I H i=\frac{Y(i)-Y(\min )}{Y(\max )-Y(\min )}$

Where IHi is the life expectancy index for individual (i); Y(i) is the life expectancy of an individual (i) which was adjusted for age, and sex. Then Y (max) and $\mathrm{Y}(\mathrm{min})$ is an international standard data for the maximum and minimum life expectancy which is taken from WHO by considering the distribution among the countries.
The final stage is to calculate the life expectancy index for households " $h "$ obtained from the average index for the entire family:

$I H H=\Sigma(I H i / n)$

where $\mathrm{n}$ is the number of household members in the household " $h "$.

The fourth stage, multiplies the index obtained on each indicator with respective weights to obtain an index of the macro and micro dimensions:

$\mathrm{X}_{1}=0.30 \mathrm{X}_{11}+0.40 \mathrm{X}_{12}+0.30 \mathrm{X}_{13}$

where,

$\mathrm{X}_{1}$ : Index of macro dimension

$\mathrm{X}_{11}$ : Indicator index of regulation

$\mathrm{X}_{12}$ : Indicator index of government budget support

$\mathrm{X}_{13}$ : Indicator index of database of zakat institutions

$X_{2}=0.40 X_{21}+0.60 X_{22}$

where,

$\mathrm{X}_{2}$ : Index of micro dimension

$\mathrm{X}_{21}$ : Indicator index of institution

$\mathrm{X}_{22}$ : Indicator index of zakat impact

The last stage is multiplying the index obtained on each dimension with respective weights to obtain a National Zakat index, which is:

$\mathrm{IZN}=0.40 \mathrm{X}_{1}+0.60 \mathrm{X}_{2}$

where,

$\mathrm{X}_{1}$ : Index of macro dimension

$\mathrm{X}_{2}$ : Index of micro dimension

\section{RESULTS AND DISCUSSION}

Based on the NZI measurement, the zakat condition in Central Java province falls in the fairly good category with an index value of 0.412 . This result comes from two 
dimensions: macro and micro. Details of the results can be observed in Table 4 .

Table 4. National Zakat Index (NZI) in Central Java Province

\begin{tabular}{lcc}
\hline No & Dimension & Index Score \\
\hline 1 & Macro & 0.025 \\
2 & Micro & 0.67 \\
NZI score in Central Java Province & \\
$=0.40(0.025)+0.60(0.67)$ & \\
$=0.412$ & \\
\hline \multicolumn{2}{l}{ Source: Primary data (2017) } &
\end{tabular}

Regarding the macro dimension, Central Java Province has an index 0.025. This means that in the macro dimension, the zakat performance BAZNAS Central Java province is not optimal. This dimension consists of three indicators: regulation, local government budget support to BAZNAS Central Java Province, and the database of zakat institutions in BAZNAS Central Java Province.

With respect to the regulation indicator, BAZNAS Central Java Province did not have a local regulation about zakat. Thus, on this indicator, BAZNAS Central Java Province has an index score of 0 . Moreover, this region also did not allocate its local government budget for the operational cost of zakat activities. So, it has an index score of 0 .

Zakat institution database indicator has three variables. The first variable, official zakat institution, has an index value of 0.25 . The second variable is the ratio of the individual muzakki and has an index value of 0 . The third variable is the enterprise muzakki ratio, which has an index value of 0 . Thus, the value of the zakat institutions database indicator index is 0.0825 . This indicator has the highest score among other indicators on the macro dimension. Thus, details of the macro dimension score is illustrated in Table 5.

Table 5. Macro Dimension Index Score

\begin{tabular}{llc}
\hline No & \multicolumn{1}{c}{ Indicator } & Index Score \\
\hline 1 & Regulation $\left(\mathrm{X}_{11}\right)$ & 0.00 \\
2 & Local government budget support $\left(\mathrm{X}_{12}\right)$ & 0.00 \\
3 & Database of zakat institution in Central Java province & 0.0825 \\
& $\quad\left(\mathrm{X}_{13}\right)$ & \\
Index score of macro dimension in Central Java Province & \\
$=0,30 \mathrm{X} 11+0,40 \mathrm{X} 12+0,30 \mathrm{X} 13$ & \\
$=0,30(0)+0,4(0)+0,30(0,0825)$ & \\
$=0,025$ & \\
\hline Source $:$ Primary data $(2017)$ &
\end{tabular}

The next dimension is micro dimension. Micro dimensions of the national zakat index consists of two indicators, namely institutional and impact of zakat. Institutional indicator has four variables: derivatives collection, management, distribution, and reporting. The zakat institution indicator has three variables: derivative CIBEST welfare index, HDI modification and independence.

Within the institutional indicator, there are four variables: the collection, management, distribution and reporting. In 2015, zakat collection amounted to $\mathrm{Rp}$ $487,695,380$, while in 2016 the amount of 
zakat collected is $\mathrm{Rp} 8,612,304,620$. The growth of zakat fund that collected by BAZNAS Central Java province is $1,666 \%$. Therefore, the index of collection is 1 .

Regarding the management variable, BAZNAS Central Java as a provincial level amil zakat institution, only one of five programs launched (scholarship) had a standard operating procedure (SOP). Five of the work programs ( Central Java, Java smart, healthy Java, Central Java, caring and Java Taqwa) were prosperous. BAZNAS Central Java province does not have a strategic plan in the management of zakat funds. It also does not have ISO certification/quality management and annual work program. Therefore, from the management indicator, BAZNAS province has an index 0.25.

On the zakat distribution variable, BAZNAS Central Java province scored 100.1 percent for the Allocation to Collection Ratio (ACR). The collection ratio (ACR) was also seen from the side of the program conducted by the zakat. It also has a good Social Program (SP), Economic Program (EP), and Dakwah Program (DP). Therefore, the index score is 1.

The next variable, zakat reporting, had an index score of 0.25 . This means that the zakat reporting by BAZNAS
Central Java Province is in the less good category. This is because financial report were not audited externally. From all the institutional indicator variables, it falls in the good category with index value of 0.70, which means that BAZNAS East Lampung Regency has a good institutional performance.

For the CIBEST welfare index, the material and spiritual welfare has an index score of 1 . This score shows that the zakat performance to mustahik welfare in Central Java Province is in the very good category. Meanwhile, education and health measurements, using a modified HDI, have an index score of 0.25 . This index measures the life viability of mustahik through their life expectancy assessment and level of education. The score of this modified HDI variable showed that the education and health condition of mustahik in Central Java Provinceranks in the less good category. The same score applies to the Independency variable. This variable illustrates the level of mustahik independency, which is measured by their occupation or business, and their savings. The index score of the Independency variable in Central Java Province is 0.75 . Therefore the occupation and savings of the mustahik in this region is in the good category.

Table 6. Micro Dimension Index Score

\begin{tabular}{lcc}
\hline No & Indicator & Index Score \\
\hline 1 & Institution $\left(\mathrm{X}_{21}\right)$ & 0.70 \\
2 & Zakat Impact $\left(\mathrm{X}_{22}\right)$ & 0.65 \\
Index score of micro dimension in Central Java Province & \\
$=0,40 \mathrm{X} 21+0,60 \mathrm{X} 22$ & \\
$=0,40(0,7)+0,6(0,65)$ & \\
$=0,67$ & \\
\hline
\end{tabular}

Source : Primary Data (2017)

The measurement of variables of the zakat impact indicator scored 0.65. This means that the zakat impact for mustahik in Central Java Province ranks in the good category. Thus, the index score of institutional indicator (0.70) and zakat impact indicator (0.65) resulted an index value of 0.60 for the micro dimension. This shows that on the micro side, the zakat condition in Central Java Province, 
especially for the performance of BAZNAS Central Java Province is good. The details of micro dimension index score can be seen in Table 6 .

\section{CONCLUSION AND RECOMMENDATION}

Generally, by using the NZI calculation, the zakat condition in Central Java Province is in the fairly good category with index value of 0.412 . On the macro dimension, the zakat condition in Central Java Province is in the not good condition with a score of 0.025 . With respect to the micro dimension, the zakat condition in Central Java Province, especially for the performance of BAZNAS Central Java Province, is in the good category with an index value of 0.67 .

This paper recommends several steps to improve the zakat condition in Central Java Province. In the macro dimension, Central Java Provincial government needs to establish a local regulation on the management of zakat and include operational costs for BAZNAS Central Java Province as an item in the regional income and expenditure budget (APBD). In addition, the database of zakat institution also needs to be better equipped. BAZNAS Central Java Province also needs to raise public awareness of zakat so that the number of individual and muzaki institutions are able to increase, subsequently optimizing the potential of zakat. Although the zakat performance of Central Java Province on the micro dimensions is good, there are some indicators that should be a concern for BAZNAS Central Java province that are related to management and reporting.

\section{REFERENCES}

Abdullah, N., Yusop MMM., and Awang COH. (2012). A Technical Note on The Derivation of Zakat
Effectiveness Index (ZEIN), International Journal of Economic, Management and Accounting, 20(1), pp. 75-86.

Badan Pusat Statistik, (2015). Statistik Indonesia 2015. Jakarta: BPS.

Badan Amil Zakat Nasional Provinsi Jawa Tengah (2016). Laporan Realisasi 2016. Semarang : BAZNAS Provinsi Jawa Tengah.

Badan Pusat Statistik Jawa Tengah. (2016). Statistik Jawa Tengah 2016. Semarang : BPS.

Badan Pusat Statistik Kota Semarang. (2016). Statistik Kota Semarang 2016. Semarang : BPS.

Beik IS. (2009). Analisis Peran Zakat dalam Mengurani Kemiskinan : Studi Kasus Dompet Dhuafa Republika, Jurnal Pemikiran dan Gagasan, 3.

Beik IS., and Arsyianti LD. (2015). Construction of CIBEST Model as Measurement of Poverty and Welfare Indicesfrom Islamic Perspective, Al-iqtishad, 3 (1).

Beik IS., and Arsyianti LD. (2016). Ekonomi Pembangunan Syariah Edisi Revisi. Jakarta: PT RajaGrafindo Persada.

Firdaus, M, Beik, IS, Irawan, T, and Juanda, B (2012). "Economic Estimation and Determinations of Zakat Potential in Indonesia", IRTI Working Paper Series, WP\# 143307.

Kementerian Agama RI. (2010). Data Penduduk Muslim. Jakarta : Kemenag RI.

Noor AHM, Rasool MSA, Ali RMYSM. and Rahman RA. (2015). Efficiency of Islamic Institution : Empirical Evidence of Zakat Organizations' Performance in Malaysia. Journal of Economics, Business and Management. 3 (2).

Nurzaman MS. (2011). Zakat and Human development : An Empirical Analysis on Poverty Alleviation in Jakarta, Indonesia. $8^{\text {th }}$ International 
Conference on Islamic Economics and Finance.

Pusat Kajian Strategi BAZNAS. (2016). Indeks Zakat Nasional. Jakarta : Puskas BAZNAS.

Torre RDL and Moreno H. (2010). Advances in sub national measurement of the Human Development Index: The case of Mexico, Human Development Research Paper.
Isro'iyatul Mubarokah

Bogor Agricultural University Indonesia

isroiyatul@gmail.com

Irfan Syauqi Beik

Bogor Agricultural University Indonesia

Tony Irawan Bogor Agricultural University Indonesia 